\title{
Relationship between the occurrence of filamentous bacteria on Bathymodiolus azoricus shell and the physiological and toxicological status of the vent mussel
}

\author{
I. Martins ${ }^{a,}{ }^{*}$, A. Colaço ${ }^{a}$, R. Serrão Santos ${ }^{a}$, F. Lesongeur ${ }^{b}$, A. Godfroy ${ }^{b}$, P.-M. Sarradin ${ }^{c}$ and \\ R.P. Cosson ${ }^{\mathrm{d}}$
}

\footnotetext{
a IMAR, DOP — Department of Oceanography and Fisheries, University of the Azores, 9901-862 Horta, Portugal

b Ifremer DEEP/Laboratoire de Microbiologie des Environnements Extrêmes, UMR6197, BP 70, 29280 Plouzané, France

${ }^{c}$ Ifremer, DEEP/Laboratoire Environnement Profond, BP 70, 29280 Plouzané, France

' Université de Nantes, Laboratoire de Biologie Marine, ISOMer, EA 2160, BP 92208, 44322 Nantes, France
}

*: Corresponding author : I. Martins, Tel.: +351 292200457; fax: +351 292200411, email address : imartins@uac.pt

\begin{abstract}
:
The edifice walls of the Eiffel Tower hydrothermal vent site (Mid-Atlantic Ridge, Lucky Strike vent field) are populated with dense communities of dual symbioses harboring vent mussel Bathymodiolus azoricus, some of which are covered by white filamentous mats belonging to sulfur-oxidizing bacteria. Mussels were collected in both the presence and absence of the filamentous bacteria. A sample of the filamentous bacteria was collected and water measurements of temperature, $\mathrm{CH}_{4}$ and $\mathrm{H}_{2} \mathrm{~S}$ were recorded at the collection area. The whole soft tissues were analyzed for total lipid, carbohydrate and total protein. Metallothioneins and metals ( $\mathrm{Cu}, \mathrm{Fe}$ and $\mathrm{Zn}$ ) levels were determined in the major organs. The results showed no significant physiological and toxicological evidence that emphasizes the influence of associated sulfur-oxidizing filamentous bacteria on $B$. azoricus mussel shells. However, $B$. azoricus mussel seems to be well adapted to the assorted physico-chemical characteristics from the surrounding environment since it is able to manage the constant fluctuation of physico-chemical compounds.
\end{abstract}

Keywords: Biomarkers; Eiffel Tower; Filamentous bacteria; Metallothioneins; Metals; Vent mussel 


\section{Introduction}

Lucky Strike is one of the largest known active vent fields ( $\left.37^{\circ} 18^{\prime} \mathrm{N}, 32^{\circ} 16^{\prime} \mathrm{W}\right)$, located in the Mid-Atlantic Ridge between 1730 and $1736 \mathrm{~m}$ depth. The hydrothermal fluid, emitted at temperature ranging between 170 and $324{ }^{\circ} \mathrm{C}$, presents characteristics (temperature, chlorinity, gas and metal concentration) that vary from site to site within the field (Charlou et al., 2000 J.L. Charlou, J.P. Donval, E. Douville, P. Jean-Baptiste, J. Radford-Knoery, Y. Fouquet, A. Dapoigny and M. Stievenard, Compared geochemical signatures and the evolution of Menez Gwen $\left(37^{\circ} 50^{\prime} \mathrm{N}\right)$ and Lucky Strike $\left(37^{\circ} 17^{\prime} \mathrm{N}\right)$ hydrothermal fluids, south of the Azores triple junction on the Mid-Atlantic Ridge, Chem. Geol. 171 (2000), pp. 49-75. Article | PDF (602 K) | View Record in Scopus | Cited By in Scopus (71)Charlou et al., 2000). The hydrothermal vent area is distributed around a lava lake, bound by the summits of three volcanic cones (Radford-Knoery et al., 1998). Both well-defined active chimneys such as Eiffel Tower belching out very hot fluids and zones where hydrothermal activity is more diffuse, can be found at Lucky Strike (Desbruyères et al., 2001). Eiffel Tower, located at 200 $\mathrm{m}$ from the southeastern edge of the circular lava lake, consists of chimneys combined into an edifice rising $7 \mathrm{~m}$ above the neighboring seafloor (Radford-Knoery et al., 1998). The structure presents numerous high temperature smokers and cracks emitting lower temperature fluids. It is colonized nearly uniformly by the vent mussel Bathymodiolus azoricus, several patches of mussel 
47 been covered by dense white filamentous microbial mats (Sarradin et al., 1999; 48 Desbruyères et al., 2001) while other are not at all. The filamentous microbial mats are

49 mainly composed of a species of Beggiatoa (Mattison et al., 1998). This species is a 50 colonizer, very abundant in environments characterized by the presence of hydrogen 51 sulfide (Wörner and Zimmermann-Timm, 2000). These chemoautotrophic bacteria gain 52 energy by the oxidation of reduced sulfur compounds (Nelson et al., 1989; Hagen and 53 Nelson, 1997; Erbacher and Nelskamp, 2006). B. azoricus hosts "dual symbioses", 54 involving the stable coexistence of chemoautotrophic (also referred to as thiotrophic) and 55 methanotrophic bacteria harbored within the gill (Fiala-Médioni et al., 2002; Duperron et 56 al., 2005). Dual symbioses provide obvious advantages to host individuals recruiting to 57 environments where the availability of substrates is unpredictable or fluctuating 58 (Cavanaugh et al., 1992; Fiala-Médioni et al., 2002). This dual symbioses has also been 59 described in others mussel species that live in reducing environments with high sulfide 60 and methane concentrations, such as hydrothermal vents (Duperron et al., 2005; Stewart 61 et al., 2005) and cold seeps (Fisher et al., 1993). The physiology and biochemistry of the 62 hydrothermal vent mussel B. azoricus must be adapted to the rapid fluctuating 63 composition of its environment composed of a mixture of seawater and hydrothermal 64 fluid (Childress and Fisher, 1992). The presence and absence of sulfur-oxidizing 65 filamentous bacteria on the hydrothermal mussel beds could be an indicator of a 66 fluctuating environment, since these chemolithoautotrophic bacteria proliferate in 67 environments with reduced sulfur compounds (Brinkhoff and Muyzer, 1997) and grow in 68 habitats with oxic-anoxic interfaces (Moyer et al., 1995). These chemical conditions may 69 alter the chemistry of mussel habitats (LeBris et al., 2006) and consequently their 
70 physiological and toxicological condition. The aim of our investigation was to study the

71 physiological condition and metal accumulation of B. azoricus collected from a mussel

72 bed where the presence and absence of filamentous bacteria were observed.

\section{2. Material and Methods}

\section{$74 \quad$ 2.1. Sampling}

75 Samples were collected during the EXOMAR cruise (with the R/V "Atalante") in July 762005 , at $1690 \mathrm{~m}$ depth on the Eiffel Tower hydrothermal site. The mussels were sampled 77 by the manipulator arm and brought to the surface using the Remotely Operated Vehicle 78 (ROV) “Victor 6000”. Samples were collected in two neighboring areas, where mussel 79 shells were covered by filamentous bacteria (designated hereafter as "mussels + mats") or 80 not covered (designated hereafter as "mussels"). From each area 25 individuals were 81 collected and measured. Individuals from the group "mussels + mats" presented a mean 82 total length of $4.3 \mathrm{~cm}( \pm 0.5 \mathrm{SD})$ and individuals from the group "mussels" presented a 83 mean total length of $3.0 \mathrm{~cm}( \pm 0.3 \mathrm{SD})$. For each group, the whole soft tissues of 15 84 mussels were separated from the shells and kept frozen $\left(-80^{\circ} \mathrm{C}\right)$ until lyophilization and 85 analysis. Left 10 mussels were dissected into gill, mantle, foot, digestive gland and 86 remaining soft tissues and kept frozen $\left(-80^{\circ} \mathrm{C}\right)$ until lyophilization and analysis. A sample 87 of microbial mats, that covered the mussels, was collected using the water pumping 88 device of the ROV "VICTOR 6000". Water samples (5 litres) were filtered on board and 89 filters were preserved at $-80^{\circ} \mathrm{C}$ for further analysis.

\section{2.2. Lipid analysis}

91 Because of small soft tissue weights, 5 mussels were pooled together for single 92 measurement of total lipids levels at each group. The lipid content was determined 
93 according to the modified method of Bligh and Dyer (1959) by extracting lipids from a

94 dry powdered in a water-dichloromethane-methanol mixture and by weighing after

95 evaporation to dryness, the organic layer. Level was expressed as $\mathrm{mg} \mathrm{g}^{-1}$ of dry weight.

96 2.3. Carbohydrate analysis

97 The whole soft tissue of 5 individuals from each group of mussels was used for 98 carbohydrate analysis. The carbohydrate content was determined colorimetrically in a $99 \mathrm{NaCl}$ extract, in the presence of $5 \%$ phenol and concentrated $\mathrm{H}_{2} \mathrm{SO}_{4}$, as described by 100 Dubois et al. (1956). The concentration was determined in glucose equivalents from a 101 glucose calibration curve using glucose as a standard. The levels of carbohydrate were 102 expressed as $\mathrm{mg} \mathrm{g}^{-1}$ of dry weight.

\section{2.4. Samples preparation for total protein, metallothionein and metal analyses}

104 The tissues of the 10 dissected mussels from each group, were lyophilized, weighed and

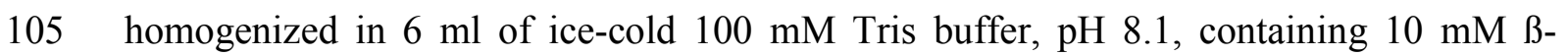
106 mercaptoethanol. The homogenates were centrifuged for $30 \mathrm{~min}$ at $25000 \mathrm{~g}$, at $4^{\circ} \mathrm{C}$ to 107 separate the supernatants $\left(S_{1}\right)$ from the insoluble fraction (pellets), used for the study of 108 intracellular metal distribution. Aliquots $(1 \mathrm{ml})$ of the $\mathrm{S}_{1}$ were used for metallothioneins 109 determination. Pellets and remaining supernatants were digested in an Ethos Plus 110 microwave oven with $5 \mathrm{ml}$ of $\mathrm{HNO}_{3}(69 \% \mathrm{v} / \mathrm{v})$ for metal analysis.

\section{$111 \quad$ 2.4.1. Total protein analysis}

112 Total protein levels were determined in supernatants $S_{1}$ from whole soft tissues of 5 113 individuals from each group of mussels, following the BioRad protein assay kit for the 114 Bradford method (Bradford, 1976). BSA (Bovine Serum Albumin) was used as reference 115 standard. Results were expressed as $\mathrm{mg} \mathrm{g}^{-1}$ of dry weight. 


\subsubsection{Metallothionein and metal analysis}

117 The aliquot of the supernatant $\mathrm{S}_{1}$, was heat-denatured $\left(90^{\circ} \mathrm{C}, 15 \mathrm{~min}\right)$ and centrifuged (13

$118000 \mathrm{~g}, 10 \mathrm{~min}$, at $4^{\circ} \mathrm{C}$ ) in order to separate the thermostable metallothioneins (MTs) from

119 thermolabile proteins. The heat stable fractions $\left(\mathrm{S}_{2}\right)$ were used for quantification of MTs

120 by Differential Pulse Polarography (DPP) according to Olafson and Sim (1979) improved

121 by Thompson and Cosson (1984). A standard addition calibration curve was obtained

122 using rabbit liver MT-I as reference. Results were expressed as $\mathrm{mg} \mathrm{g}^{-1}$ of dry weight.

123 After pellets and remaining supernatant $\mathrm{S}_{1}$ digestion, solutions were dried at $60^{\circ} \mathrm{C}$ and 124 diluted by adding $2 \mathrm{ml} 0.5 \mathrm{~N} \mathrm{HNO}_{3}$. Metal levels $(\mathrm{Cu}, \mathrm{Fe}, \mathrm{Zn})$ were measured by flame 125 atomic absorption spectrophotometry (AAS) with deuterium background correction. The 126 accuracy and precision of the method used were established by regular analysis of 127 certified reference materials of mussel tissue CE278 (European Reference Materials of 128 Belgium) and lobster hepatopancreas TORT-2 (National Research Council of Canada) (Table 1).

129 Certified reference materials and blanks were taken through the procedure in the same 130 way as the samples. Metal levels were calculated and expressed as $\mathrm{mg} \mathrm{g}^{-1}$ of dry weight.

\section{2.5. Microbial mat molecular diversity}

132 A preliminary study of the microbial mat diversity was performed by using 16S rRNA 133 gene sequencing. DNA was extracted from frozen mat sample pellets as described in 134 Alain et al. (2002). Archaeal DNA was amplified using the primer A24F (5'-TTC CGG 135 TTG ATC CTG CCG GA-3') and the reverse primer 1407R (5'-GAC GGG CGG TGW 136 GTR CAA-3'). Bacterial DNA was amplified using the primer E8F (5'-AGA GTT TGA 137 TCA TGG CTC AG-3') and the reverse primer U1492R (5'-GTT ACC TTG TTA CGA 138 CTT-3'). PCR reactions were performed on a Robocycler Gradient 96 (Stratagene) (Wery 139 et al., 2002; Nercessian et al., 2003). PCR products were then checked on a $0.8 \%(\mathrm{w} / \mathrm{v})$ 
140 agarose gel and directly cloned using the TOPO TA Cloning® kit (pCR2.1 vector),

141 according to the manufacturer's instructions (Invitrogen). Sequences were analyzed as

142 previously described by Postec et al. (2005).

143 2.6. In situ temperature measurements, $\mathrm{CH}_{4}$ and $\mathrm{H}_{2} \mathrm{~S}$ estimated values

144 Eight autonomous temperature probes (thermistor, Vemco Minilog 12 TR 64K probes)

145 were deployed on each sampling point for two days. The temperature data were corrected

146 against the bottom seawater temperature $\left(4.4^{\circ} \mathrm{C}\right)$. The sampling period was 30 seconds.

$147 \mathrm{CH}_{4}$ concentrations were estimated using the significant Temperature/ $\mathrm{CH}_{4}$ linear 148 relationship obtained during the ATOS cruise on 16 samples from the Eiffel Tower 149 edifice (Sarradin et al., 2003). Total sulfide $(\Sigma S)$ concentrations were estimated using the 150 significant Temperature/ $\Sigma \mathrm{S}$ linear relationship obtained in 2006 during the MoMARETO 151 cruise with the CHEMINI in situ chemical analyzer (Vuillemin et al., 2009). Results were 152 expressed as $\mu \mathrm{mol} 1^{-1}$.

\section{$153 \quad 2.7$. Statistical analysis}

154 All the results are given as mean level by individual/tissues dry weight. The statistical 155 calculations were performed with STATISTICA software (6.0 release, StatSoft). Data 156 were checked for normal distribution and homogeneity of variance (Leven's test). Non157 parametric tests (Kruskall-Wallis and Mann-Whitney) were performed when data were 158 not normally distributed or when they exhibited heterogeneous variances.

159 3. Results

160 3.1. Biochemical composition 
161 Lipid, carbohydrate and total protein results per group of mussels, are shown in Table 2.

162 No significant difference was found between the two groups of mussels (Mann-Whitney,

$163 \mathrm{p}>0.05$ ) for lipid, carbohydrate and total protein levels.

\section{3.2. Preliminary microbial mat diversity study}

165 Phylogenetic analysis of bacterial clone library evidenced a very large diversity of 166 uncultured bacteria within the $\alpha, \delta, \gamma$ and $\varepsilon$-proteobacteria. Bacteria belonging to

167 Cytophaga/Flavobaceria/bacteroides group, planctonomycetes and actinombacteria were 168 detected. Within the $\gamma$-proteobacteria, sequences belonging to order Thiotricales were 169 identified. The order Thiotricales includes the filamentous sulfur-oxidizing bacteria such 170 as Beggiatoa, Thioploca and Thiotrix. The archaeal diversity appeared to be very low. All 171 the sequences were located in the marine Crenarcheaota group I and dominated by one 172 phylum closely related to the newly described (and first cultivated species within this 173 group) ammonia-oxidizing Crenarchaeota "Nitrosopumilus maritimus" (Konneke et al., 174 2005). Microscopic observation showed the presence of large intracellular vacuoles 175 surrounded with sulfur granules in some large bacterial filaments, described earlier in 176 many of sulfur-oxidizing species (Godfroy, personal observation).

\section{3.3. In situ temperature measurements, $\mathrm{CH}_{4}$ and $\mathrm{H}_{2} \mathrm{~S}$ estimated values}

178 Table 3 presents the results of the temperature measured, $\mathrm{CH}_{4}$ and $\mathrm{H}_{2} \mathrm{~S}$ estimated values 179 at the environment surrounding the two groups of mussels studied. The temperatures 180 measured within the two groups presented significant differences (Mann-Whitney, $181 \mathrm{p}<0.05) . \mathrm{CH}_{4}$ and $\mathrm{H}_{2} \mathrm{~S}$ estimated values are distinct between the two groups of mussels.

182 The temperature measured as well as both estimated values of $\mathrm{CH}_{4}$ and $\mathrm{H}_{2} \mathrm{~S}$ presented 183 higher mean in the group "mussels + mat" than "mussels" group. The temperature 
184 standard deviation, minimum, maximum and range were also higher in the environment

185 characterized by the presence of microbial mats. The increase of relative temperature, 186 compared to ambient seawater temperature $\left(4.4^{\circ} \mathrm{C}\right)$, was $+0.2^{\circ} \mathrm{C}$ within the "mussels" 187 group and up to $+3{ }^{\circ} \mathrm{C}$ within the "mussels + mat" group. The temperature variations 188 sustained by the "mussels" group were less extensive than those faced by "mussels + mat" 189 group. Assuming that temperature can be used as a semi conservative tracer of the vent 190 fluid dilution (Johnston et al., 1988; LeBris et al., 2006), it is possible to estimate the 191 hydrothermal input in the studied environment using the ambient seawater $\left(4.4^{\circ} \mathrm{C}\right)$ and 192 the undiluted hydrothermal fluid $\left(324^{\circ} \mathrm{C}\right)$ temperatures (Charlou et al., 2000). 193 Consequently, the input of hydrothermal fluid observed in the sampled sites ranged 194 between $0.2 \%$ at a temperature of $4.9^{\circ} \mathrm{C}$ to $1 \%$ at a temperature of $7.4^{\circ} \mathrm{C}$.

\section{3.4. Metallothionein and metal levels}

196 Table 4 shows the levels of metals and metallothionein (MT) in the different tissues of 197 both mussel groups. Results are presented by tissue analyzed and by group of mussels. 198 Metal in the vent mussel can be ranked in the following order according to the levels 199 found: $\mathrm{Fe}>\mathrm{Zn}>\mathrm{Cu}$, for individuals from the group "mussels" and $\mathrm{Zn}>\mathrm{Fe}>\mathrm{Cu}$, for 200 individuals from the group "mussels + mat". Only at group "mussels" were found 201 significant differences (Kruskal-Wallis, $\mathrm{p}<0.05$ ) between the metal levels.. The digestive 202 gland was the organ which presented the highest levels of metals and MT. In this organ $203 \mathrm{Fe}$ levels were found statistically different between groups (Kruskal-Wallis, $\mathrm{p}<0.05$ ), 204 with higher levels found at "mussels" group. No significant difference (Kruskal-Wallis, $205 \mathrm{p}>0.05$ ) was found between the distribution (soluble/insoluble fractions) of metals within 
206 the analyzed tissues. Metallothionein levels in the digestive gland are not statistically

207 different between groups (Mann-Whitney, $\mathrm{p}>0.05$ ).

208 4. Discussion

209 4.1. Physiological status

210 The dual endosymbiosis involving sulfur and methane oxidizers is one of the mechanisms

211 developed by B. azoricus to use the chemical energy of hydrothermal environment. There

212 is some empirical evidence that the relative abundance of dual symbiosis in this species

213 can vary in response to environmental parameters (Fiala-Médioni et al., 2002; Duperron

214 et al., 2005). Moreover, studies carried out in Eiffel Tower site demonstrate a higher

215 concentration of sulfide $(2.1 \mathrm{mM})$ than methane $(0.68 \mathrm{mM})$ in end-member fluids

216 (Charlou et al., 2000) and accordingly, a dominance of chemoautotrophic symbionts in

217 the gills of B. azoricus from this site (Trask and Van Dover, 1999; Salerno et al., 2005;

218 Duperron et al., 2006). The estimated values of $\mathrm{CH}_{4}$ and $\mathrm{H}_{2} \mathrm{~S}$ presented in this study lead

219 us to consider that each group of mussels has different energy sources. The site where

220 "mussels + mats" were collected, presented higher $\mathrm{H}_{2} \mathrm{~S}$ values than the site "mussels" are

221 living at. $\mathrm{H}_{2} \mathrm{~S}$ contributes to the proliferation of these sulfur-oxidizing filamentous

222 bacteria that uses the sulfide and the oxygen available (Wörner and Zimmermann-Timm,

223 2000) in their proximal environment. The symbiotic sulfur-oxidizing bacteria use the

224 energy produced by the oxidation of reduced compounds, such as sulfide, as energy

225 source to produce organic compounds, acting as primary producers for their host (Fiala-

226 Médioni et al., 2002). Therefore, it was suggested the possibility of the sulfur-oxidizing

227 filamentous bacteria consume part of the environment sulfide also needed by sulfur-

228 oxidizing symbionts. The consumption of sulfide by free-living filamentous bacteria and 
229 consequently depletion of this compound available for chemoautotrophic symbionts 230 utilization may influence the physiological status of the mussels associated with

231 filamentous bacteria. Several biochemical markers, such as lipids, carbohydrates and total

232 proteins, were use to study the possible differences on physiological condition between

233 the group "mussels + mats" and the group "mussels". The analysis of such biochemical

234 parameters in hydrothermal vent animals has proven to be a rewarding approach to 235 understand their biology (Childress and Fisher, 1992). Furthermore, lipids are an 236 important source of energy that can be used during periods of food shortage and as an 237 energy reserve for the successful larval development (Fraser, 1989). Mussels use 238 carbohydrates as energy reserves that are metabolised into lipids during egg maturation 239 (Kopp et al., 2005). Proteins are of fundamental importance in mussels as they are used in 240 several biological functions for maintenance, growth and reproduction (Olsson et al., 241 2004). Therefore, the variation of these biochemical parameters could be considered a 242 valuable indicator of organism physiological condition (Lagadic et al., 1997). The 243 "mussels + mats" group and "mussels" group did not show differences between the 244 amounts of lipids, carbohydrates and total proteins. Consequently we can not put forward 245 differences between their physiological conditions by this mean. The preliminary study 246 made in the microbial mat collected, identified the presence of several groups of free247 living bacteria including the sulfur-oxidizing filamentous type. However it is unknown, 248 for now, the relative abundance of these bacteria at the microbial mat. The similar 249 physiological status found between the two groups of $B$. azoricus mussels studied may 250 indicate a low relative abundance of sulfur-oxidizing filamentous bacteria and 251 consequently low competition for environmental sulfide. From the temperature 
252 measurements made in both collection areas, we can assume that the environment

253 surrounding the studied mussels is situated in the really cold part of the mixing zone

254 between the ambient seawater and the hydrothermal fluid (Sarradin, personal

255 observation). However, the "mussels + mats" group presented relatively high

256 temperatures, high levels of $\Sigma \mathrm{S}$ (i.e. $\mathrm{H}_{2} \mathrm{~S}, \mathrm{HS}^{-}, \mathrm{S}^{2-}$ ), low $\mathrm{pH}$ and dissolved oxygen,

257 accordingly to the proximity of fluid emissions (Sarradin et al., 1999). It is the same for

258 estimated high values for $\mathrm{CH}_{4}$ and $\mathrm{H}_{2} \mathrm{~S}$ at the "mussels + mats" group site allowing us to

259 hypothesize the proximity of fluid emissions. Furthermore, the estimated values of $\mathrm{H}_{2} \mathrm{~S}$

260 obtained in the collection area are within the range of $0-62 \mu \mathrm{M}$ for the $\mathrm{H}_{2} \mathrm{~S}$ concentration

261 reported for mussel beds in Eiffel Tower (Sarradin et al., 1999). The higher values

262 recorded for temperature, $\mathrm{CH}_{4}$ and sulfur compounds at the "mussel + mats" group site,

263 besides contributing to free-living filament bacteria proliferation, do not seem to have any

264 observed effect on B. azoricus physiological condition. Likely, B. azoricus as a

265 mixotrophic organism which obtains energy not only from a dual endosymbiosis but also

266 from suspension-feeding and can potentially regulate the relative contribution of both

267 nutritional pathways according to external conditions (Martins et al., 2008).

\section{4.2. Toxicological status}

269 The interactions between the superheated fluids and cold ocean water create a dynamic 270 system that gives, to vent organisms, periodic access to high levels of metals (Geret et al., 271 1998). Other studies put forward the high concentrations of metals in Lucky Strike 272 hydrothermal vent fluids, like $\mathrm{Cu}(2$ to $30 \mu \mathrm{M})$, Fe (70 to $920 \mu \mathrm{M})$ and $\mathrm{Zn}(2$ to $40 \mu \mathrm{M})$

273 (Charlou et al., 2000; Douville et al., 2002) and the bioaccumulation of those metals in 274 vent organisms, such as mussels (Colaço at al., 2006; Cosson, 2008). The pattern 
$275 \mathrm{Fe}>\mathrm{Zn}>\mathrm{Cu}$ found for individuals from the "mussels" group is in agreement with earlier 276 studies of B. azoricus metal bioaccumulation (Cravo et al., 2007; Kádár et al., 2007) and 277 with Lucky Strike fluids composition (Douville et al., 2002). The "mussels + mats" group 278 showed a different pattern $(\mathrm{Zn}>\mathrm{Fe}>\mathrm{Cu})$, however it was not found any statistical 279 difference between $\mathrm{Zn}$ and Fe levels in this group. Moreover, for both groups, the highest 280 accumulation of these metals was found in the digestive gland. It has been shown that 281 digestive gland of bivalves is a target organ for the bioaccumulation of metals 282 (Domouhtsidou and Dimitriadis, 2000). The ability of Bathymodiolus sp. to capture and 283 ingest mineral particles, including $\mathrm{Fe}, \mathrm{Zn}$ and $\mathrm{Cu}$ sulfides (Le Pennec et al., 1985) is one 284 pathway for bioaccumulation of metals in the digestive gland (Rousse et al., 1998). 285 Moreover, this organ has an important role in metabolism of metals and is considered as a 286 long-term storage tissue and thus a good indicator of persisting exposure (Hamza-Chaffai 287 et al., 2000). The high levels of Fe found in digestive gland of "mussels" group may be a 288 reflection of a more direct exposure of individuals to the Fe sulfide particles floating in 289 their surrounding environment. Nevertheless, one factor that can affect metal 290 bioaccumulation is body size (Pan and Wang, 2008). Studies developed by Boyden, 291 (1974) regarding mussel allometry in ecotoxicology, show that highest values of trace 292 elements are often recorded in the smallest individuals. That could be the explanation for 293 the high Fe levels found for the "mussels" group formed by individuals presenting a 294 smaller size than those from the "mussels + mats" group.

295 As metals are rather abundant at Lucky Strike hydrothermal field (Rousse et al., 1998; 296 Douville et al., 2002; Kádár et al., 2005), their intracellular distribution between soluble 297 and insoluble forms can be used to evaluate the toxicological significance of each metal. 
298 However we could not show any difference for the distribution of metals between the 299 soluble and insoluble fractions of mussels collected at the sampled locations. 300 Metallothioneins are known to be the major metal detoxification process in mussels

301 (Langston et al., 1998). The amounts of MT found in the tissues of B. azoricus from both

302 groups were in relation with the accumulation of the analyzed metals, accordingly the 303 higher amounts of MT were found in the digestive gland. However no significant 304 correlation between MT and soluble metal amounts was established. Although the 305 synthesis of MT can be enhanced by the presence of metals in the organisms there are 306 other factors such as oxidative stress and environmental changes that can also stimulate 307 the neosynthesis of these metalloproteins (Viarengo and Nott, 1993; Bebianno et al., 308 2005; Company et al., 2006). Further studies are needed regarding the relative abundance 309 of sulfur-oxidizing filamentous bacteria at the microbial mats and the putative importance 310 of suspension-feeding nutritional pathway in dual symbionts-bearing mussel B. azoricus.

\section{5. Conclusions}

312 The results presented in this study do not show significant physiological and

313 toxicological evidence that emphasize the influence of associated sulfur-oxidizing

314 filamentous bacteria on B. azoricus mussel. The physiological markers show a similar 315 physiological condition between the two groups of mussels. As well, the variations found 316 in the abiotic factors measured seem not to influence the physiological status of the two 317 mussel groups. The presence of sulfur-oxidizing filamentous bacteria regarded as an 318 indicator of elevated sulfide concentrations, point out a lesser diluted hydrothermal fluid 319 at the considered area and accordingly higher levels of metals available to the organisms.

320 However, it seems that metals are equally bioavailable for mussel in the presence and 
321 absence of sulfur-oxidizing filamentous bacteria. This work shows that, B. azoricus

322 mussel seems to be well adapted to the assorted physico-chemical characteristics from the

323 surrounding environment since it is able to manage the constant fluctuation of physico-

324 chemical compounds.

\section{Acknowledgements}

326 The authors gratefully acknowledge the captain and crew of the R/V L'Atalante and 327 Victor 6000 ROV team, during the EXOMAR cruise (IFREMER), the EU research 328 project EXOCET/D, FP6-GOCE-CT-2003-505342, the Portuguese Science Foundation 329 funded program SEAHMA project (FCT/ PDCTM 1999/MAR/15281), the pluriannual 330 and programmatic funding from FCT and DRCT for research unit \#531 and LA \#9, 331 Camões Institution- Pessoa program (GRICES/FCT). I. Martins works under a FCT PhD 332 grant (SFRH/BD/19736/2004).

\section{References}

334 Alain, K., Olagnon, M., Desbruyères, D., Page, A., Barbier, G., Juniper, K., Querellou, J., 335 Cambon-Bonavita, M-A., 2002. Phylogenetic characterization of the bacterial assemblage 336 associated with the hydrothermal vent polychaete Paralvinella palmiformis. FEMS 337 Microbiol. Ecol. 42, 1331-1339.

339 Bebianno, M.J., Company, R., Serafim, A., Camus, L., Cosson, R.P., Fiala-Médioni, A., 340 2005. Antioxidant systems and lipid peroxidation in Bathymodiolus azoricus from Mid341 Atlantic Ridge hydrothermal vent fields. Aquat. Toxicol. 75, 354-373. 
343 Bligh, E.G., Dyer, W.J., 1959. A rapid method of total lipid extraction and purification.

344 Can. J. Biochem. Physiol. 37, 911-917.

345

346 Boyden, C.R., 1974. Trace element content and body size in mollusks. Nature 251, 311$347 \quad 314$

349 Bradford, M., 1976. A rapid and sensitive method for the quantification of microgram 350 quantities of protein utilizing the principle of protein-dye binding. Anal. Biochem. 72, $351 \quad 248-254$.

353 Brinkhoff, T., Muyzer, G., 1997. Increased Species Diversity and Extended Habitat 354 Range of Sulfur-Oxidizing Thiomicrospira spp. Appl. Environ. Microbiol. 63, 37893553796

357 Cavanaugh, C.M., Wirsen, C.O., Jannasch, H.W., 1992. Evidence for methylotrophic 358 symbionts in a hydrothermal vent mussel (Bivalvia: Mytilidae) from the Mid-Atlantic 359 Ridge. Appl. Environ. Microbiol. 58, 3799-3803.

361 Charlou, J.L., Donval, J.P., Douville, E., Jean-Baptiste, P., Radford-Knoery, J., Fouquet, 362 Y., Dapoigny, A., Stievenard, M., 2000. Compared geochemical signatures and the 363 evolution of Menez Gwen $\left(37^{\circ} 50^{\prime} \mathrm{N}\right)$ and Lucky Strike $\left(37^{\circ} 17^{\prime} \mathrm{N}\right)$ hydrothermal fluids, 364 south of the Azores triple junction on the Mid-Atlantic Ridge. Chem. Geol. 171, 49-75. 
366 Childress, J.J., Fisher, C.R., 1992. The biology of hydrothermal vent animals:

367 Physiology, biochemistry and autotrophic symbioses. Oceanogr. Mar. Biol. Annu. Rev. $368 \quad 30,337-441$

369

370 Colaço, A., Bustamante, P., Fouquet, Y., Sarradin, P.M., Santos, R.S., 2006.

371 Bioaccumulation of $\mathrm{Hg}, \mathrm{Cu}$, and $\mathrm{Zn}$ in the Azores triple junction hydrothermal vent fields

372 food web. Chemosphere 65, 2260-2267.

374 Company, R., Serafim, A., Cosson, R.P., Fiala-Médioni, A., Dixon, D., Bebianno, M.J., 375 2006. Temporal variation in the antioxidant defense system and lipid peroxidation in the 376 gills and mantle of hydrothermal vent mussel Bathymodiolus azoricus. Deep-Sea Res. 377 Part I 53, 1101-1116.

379 Cosson, R.P., Thiébaut, É., Company, R., Castrec-Rouelle, M., Colaço, A., Martins, I., 380 Sarradin, P.M., Bebianno, M.J., 2008. Spatial variation of metal bioaccumulation in the 381 hydrothermal vent mussel Bathymodiolus azoricus. Mar. Environ. Res. 65, 405-415.

383 Cravo, A., Foster, P., Almeida, C., Company, R., Cosson, R.P., Bebianno, M.J., 2007.

384 Metals in the shell of Bathymodiolus azoricus from a hydrothermal vent site on the Mid385 Atlantic Ridge. Environ. Int. 33, 609-615.

387 Desbruyères, D., Biscoito, M., Caprais, J-C., Colaço, A., Comtet, T., Crassous, P., 388 Fouquet, Y., Khripounoff, A., Le Bris, N., Olu, K., Riso, R., Sarradin, P.M., Segonzac, 
389 M., Vangriesheim, A., 2001. Variations in deep-sea hydrothermal vent communities on 390 the Mid-Atlantic ridge near the Azores plateau. Deep-Sea Res. Part I 48, 1325-1346.

391

392 Domouhtsidou, G.P., Dimitriadis, V.K., 2000. Ultrastructural localization of heavy 393 metals $(\mathrm{Hg}, \mathrm{Ag}, \mathrm{Pb}$, and $\mathrm{Cu})$ in gills and digestive gland of mussels, Mytilus 394 galloprovincialis (L.) Arch. Environ. Contam. Toxicol. 38, 472-478.

396 Douville, E., Charlou, J.L, Oelkers, E.H, Bienvenu, P., Jove Colon, C.F., Donval, J.P., 397 Fouquet, Y., Prieur, D., Appriou, P., 2002. The Rainbow vent fluids (36²'N, MAR): 398 the influence of ultramafic rocks and phase separation on trace metal content in Mid399 Atlantic Ridge hydrothermal fluids. Chem. Geol.184, 37-48.

400

401 Dubois, M., Gilles, K.A., Hamilton, J.K., Rebers, P.A., Smith, F., 1956. Colorimetric 402 method for determination of sugars and related substances. Anal. Biochem. 28, 350-356. 403

404 Duperron, S., Nadalig, T., Caprais, J.C., Sibuet, M., Fiala-Médione, A., Amann, R., 405 Dubilier, N., 2005. Dual symbiosis in a Bathymodiolus sp. mussel from a methane seep 406 on the Gabon continental margin (Southeast Atlantic): 16S rRNA phylogeny and 407 distribution of the symbionts in gills. Appl. Environ. Microbiol. 71, 1694-1700.

408

409 Duperron, S., Bergin, C., Zielinski, F., Blazejak, A., Pernthaler, A., McKiness, Z.P., 410 DeChaine, E., Cavanaugh, C.M., Dubilier, N., 2006. A dual symbiosis shared by two 411 mussel species, Bathymodiolus azoricus and Bathymodiolus puteoserpentis (Bivalvia: 
412 Mytilidae), from hydrothermal vents along the northern Mid-Atlantic Ridge. Environ.

413 Microbiol. 8, 1441-1447.

414

415 Erbacher, J., Nelskamp, S., 2006. Comparison of benthic foraminifera inside and outside

416 a sulphur-oxidizing bacterial mat from the present oxygen-minimum zone off Pakistan

417 (NE Arabian Sea). Deep-Sea Res. Part I 53, 751-775.

419 Fiala-Médioni, A., McKiness, Z.P., Dando, P., Boulegue, J., Mariotti, A., Alayse-Danet, 420 A.M., Robinson, J.J., Cavanaugh, C.M., 2002. Ultrastructural, biochemical, and 421 immunological characterization of two populations of the mytilid mussel Bathymodiolus 422 azoricus from the Mid-Atlantic Ridge: evidence for a dual symbiosis. Mar. Biol. 141, 423 1035-1043.

425 Fisher, C., Brooks, J.M., Vodenichar, J.S., Zande, J.M., Childress, J.J., Burke, R.A., 426 1993. The co-occurrence of methanotrophic sulfur-oxidizing bacterial symbionts in a 427 deep-sea mussel. Mar. Ecol. 14, 277-289.

429 Fraser, A.J., 1989. Triacylglycerol content as a condition index for fish, bivalve and 430 crustacean larvae. Can. J. Fish. Aquat. Sci. 46, 1868-1873.

432 Geret, F., Rousse, N., Riso, R., Sarradin, P.M., Cosson, R.P., 1998. Metal 433 compartmentalization and metallothionein isoforms in mussels from the Mid-Atlantic 
434 Ridge; preliminary approach to the fluid-organism relationship. Cah. Biol. Mar. 39, 291435293

437 Hagen, K.D., Nelson, D.C., 1997. Use of reduced sulfur compounds by Beggiatoa spp.: 438 Enzymology and physiology of marine and freshwater strains in homogeneous and 439 gradient cultures. Appl. Environ. Microbiol. 63, 3957-3964.

441 Hamza-Chaffai, A., Amiard, J.C., Pellerin, J., Joux, L., Berthet, B., 2000. The potential 442 use of metallothionein in the clam Ruditapes decussatus as a biomarker of in situ metal 443 exposure. Comp. Biochem. Physiol. 127, 185-197.

445 Johnson, K.S., Childress, J.J., Hessler, R.R., Sakamoto-Arnold, C.M., Beelher, C.L., 446 1988. Chemical and biological interactions in the Rose Garden hydrothermal vent field. 447 Galapagos spreading center. Deep-Sea Res. Part I 35, 1723- 1744.

449 Kádár, E., Costa, V., Martins, I., Santos, R.S., Powell, J.J., 2005. Enrichment in trace 450 metals ( $\mathrm{Al}, \mathrm{Mn}, \mathrm{Co}, \mathrm{Cu}, \mathrm{Mo}, \mathrm{Cd}, \mathrm{Fe}, \mathrm{Zn}, \mathrm{Pb}$ and $\mathrm{Hg}$ ) of macro-invertebrate habitats at 451 hydrothermal vents along the Mid Atlantic Ridge. Hydrobiologia 548, 191-205.

453 Kádár, E., Costa, V., Segonzac, M., 2007. Trophic influences of metal accumulation in 454 natural pollution laboratories at deep-sea hydrothermal vents of the Mid-Atlantic Ridge. 455 Sci. Total Environ. 373, 464-472. 
457 Konneke, M., Bernhard, A.E., De La Torre, J.R., Walker, C.B., Waterbury, J.B., Stahl, 458 D.A., 2005. Isolation of an autotrophic ammonia-oxidizing marine archaeon. Nature 437, $459 \quad 543-546$.

460

461 Kopp, J., Cornette, F., Simmone, C., 2005. A comparison of growth and biochemical 462 composition of Mytilus galloprovincialis (Lmk.) and Mytilus edulis (L.) on the West 463 coast of Cotentin, Normandy, France 1999-2000. Aquac. Int.13, 327-340.

464

465 Lagadic, L. Caquet, T., Amiard, J.C., 1997. Biomarqueurs en ecotoxicologie: Principes et 466 definitions. In: Lagadic, L., Caquet, T., Amiard, J.C., Ramade, F., (Eds.), Biomarqueurs 467 en ecotoxicologie. Aspects Fondamentaux, Paris, pp. 1 -9. 468

469 Langston, W.J., Bebianno, M.J., Burt, G.R., 1998. Metal handling strategies in molluscs. 470 In: Langston, W.J. Bebianno, M.J., (Eds.), Metal metabolism in aquatic environments. 471 Chapman and Hall, London, pp. 219-283.

473 Le Bris, N., Govenar, B., Le Gall, C., Fisher, C.R., 2006. Variability of physico-chemical 474 conditions in 9850VN EPR diffuse flow vent habitats. Mar. Chem. 98, 167-182.

476 Le Pennec, M., Prieur, D., Lucas, A. 1985. Studies on the feeding of a hydrothermal-vent 477 mytilid from the East Pacific Rise. In: Gibbs, P.E., (Eds.), Proceedings of the nineteenth 478 European marine biology symposium, 16-21 September 1984, Plymouth, Devon, U.K., $479 \quad 159-165$. 
481 Martins I., Colaço, A., Dando, P.R., Martins, I., Desbruyères, D., Sarradin, P.M., 482 Marques, J.C., Santos, R.S, 2008. Size-dependent variations on the nutritional pathway of 483 Bathymodiolus azoricus demonstrated by a C-flux model. Ecol. Model. 217: 59-71.

485 Mattison R.G., Abbiati, M., Dando, P.R., Fitzsimons, M.F., Pratt, S.M., Southward, A.J., 486 Southward, E.C., 1998. Chemoautotrophic microbial mats in submarine caves with 487 hydrothermal sulphidic springs at Cape Palinuro, Italy. Microb. Ecol. 35, 58-71.

489 Moyer, C., Dobbs, F.C., Karl, D.M., 1995. Phylogenetic diversity of the bacterial 490 community from a microbial mat at an active, hydrothermal vent system, Loihi seamount, 491 Hawaii. Appl. Environ. Microbiol. 61, 1555-1562.

493 Nelson D.C., Wirsen, C.O., Jannassch, H.W., 1989. Characterization of large, autotrophic 494 Beggiatoa spp. abundant at hydrothermal vents of the Guayamas Basin. Appl. Environ. 495 Microbiol. 55, 2909-2917.

496

497 Nercessian, O., Reysenbach, A.L., Prieur, D., Jeanthon, C., 2003. Archaeal diversity 498 associated with in situ samplers deployed on hydrothermal vents on the East Pacific Rise $499\left(13^{\circ} \mathrm{N}\right)$. Environ. Microbiol. 5, 492-502.

501 Olafson, R.W., Sim, R.G., 1979. An electrochemical approach to quantification and 502 characterization of metallothioneins. Anal. Biochem. 100, 343-351. 
504 Olsson, B., Bradley, B.P., Gilek, M., Reimer, O., Shepard, J.L., Tedengren, M., 2004.

505 Physiological and proteomic responses in Mytilus edulis exposed to PCBs and PAHs 506 extracted from Baltic Sea sediments. Hydrobiologia 514, 15-27.

507

508 Pan, K., Wang, W-X., 2008. Allometry of cadmium and zinc concentrations and 509 bioaccumulation in the scallop Chlamys nobilis. Mar. Ecol. Prog. Ser. 365, 115-126.

511 Postec, A., Urios, L., Lasongeur, F., Ollivier, B., Querellou, J., Godfroy, A., 2005.

512 Continuous enrichment culture and molecular monitoring to investigate the microbial 513 diversity of thermophiles inhabiting the deep-sea hydrothermal ecosystems. Curr. 514 Microbiol. 50, 138-144.

516 Radford-Knoery, J., Charlou, J.L., Donval, J.P., Aballéa, M., Fouquet, Y., Ondréas, H., 517 1998. Distribution of dissolved sulfide, methane, and manganese near the seafloor at the 518 Lucky Strike $\left(37^{\circ} 17^{\prime} \mathrm{N}\right)$ and Menez Gwen $\left(37^{\circ} 50^{\prime} \mathrm{N}\right)$ hydrothermal vent sites on the Mid519 Atlantic Ridge. Deep-Sea Res. Part I 45, 367-386.

521 Rousse, N., Boulegue, J., Cosson, R.P., Fiala-Medioni, A., 1998. Bioaccumulation des 522 métaux chez le mytilidae hydrothermal Bathymodiolus sp. de la ride médio-atlantique. 523 Oceanol Acta 21, 597-607. 
525 Salerno J. L., Macko, S. A., Hallam, S. J., Bright, M., Won, Y-J., Mckiness Z., Van

526 Dover, C L., 2005. Characterization of symbiont populations in life-history stages of 527 mussels from chemosynthetic environments. Biol. Bull. 208, 145-155.

528

529 Sarradin, P.M., Caprais, J.C., Riso, R., Kerouel, R., Aminot, A., 1999. Chemical

530 environment of the hydrothermal mussel communities in the Lucky Strike and Menez

531 Gwen vent fields, Mid Atlantic Ridge. Cah. Biol. Mar. 40, 93-104.

532

533 Sarradin P.M., Desbruyères, D., Le Bris, N., Caprais, J.C., Rodier, P., Fabri, M.C., Le

534 Gall, C., Khripounoff, A., Vangriesheim, A., Crassous, P., Briand, P., Segonzac, M.,

535 Fouquet, Y., Cambon, P., Etoubleau, J., Riso, R., 2003. Ventox WP5:

536 Organisms/Fluid/Substrate interactions, final data report, Ifremer, Brest, 28 pp.

538 Stewart, F., Newton, I., Cavanaugh, C., 2005. Chemosynthetic endosymbiosis:

539 adaptations to oxic-anoxic interfaces. Trends Microb. 13, 439-448.

541 Trask, J.L., Van Dover, C.L., 1999. Site-specific and ontogenetic variations in nutrition

542 of mussels (Bathymodiolus sp.) from the Lucky Strike hydrothermal vent field, Mid-

543 Atlantic Ridge. Limnol. Oceanogr. 44, 334-343.

545 Thompson, J.J., Cosson, R.P., 1984. An improved electrochemical method for the 546 quantification of metallothioneins in marine organisms. Mar. Environ. Res 11, 137-152. 
548 Viarengo, A., Nott, J.A., 1993. Mechanisms of heavy metal cation homeostasis in marine 549 invertebrates. Comp. Biochem. Physiol. 104, 355-372.

550

551 Vuillemin, R., LeRoux, D., Dorval, P., Bucas, K., Sudreau, J.P., Hamona, M., LeGall, C., 552 Sarradin, P.M., (2009). CHEMINI: A new in situ CHEmical MINIaturized analyzer. 553 Deep-Sea Res. Part I, in press

554

555 Wery, N., Cambon-Bonavita, M.A., Lesongeur, F., Barbier, G., 2002. Diversity of 556 anaerobic heterotrophic thermophiles isolated from deep-sea hydrothermal vents of the 557 Mid-Atlantic Ridge. FEMS Microbiol. Ecol. 41, 105-114.

558

559 Wörner, U., Zimmermann-Timm, H., 2000. Beggiatoa leptomitiformis- a filamentous 560 sulfur-oxidizing bacterium colonizing laboratory-made aggregates. Limnologica 30, 215561221.

562

563

564

565

566 
1 Table 1

2 Levels of $\mathrm{Cu}, \mathrm{Fe}$ and $\mathrm{Zn}$ found in certified reference material, mussel tissue CE278 (ERM-Belgium) and lobster hepatopancreas TORT-2 (NRCC-Canada).

3 Results as mean $\pm \mathrm{SD}$, in $\mathrm{mg} \mathrm{g}^{-1}$ dry weight.

\begin{tabular}{llccc}
\hline $\begin{array}{l}\text { Certified reference } \\
\text { material }\end{array}$ & & $\begin{array}{c}\mathrm{Cu}\left(\mathrm{mg} \mathrm{g}^{-1}\right) \\
\mathrm{n}=6\end{array}$ & $\begin{array}{c}\mathrm{Fe}\left(\mathrm{mg} \mathrm{g}^{-1}\right) \\
\mathrm{n}=8\end{array}$ & $\begin{array}{c}\mathrm{Zn}\left(\mathrm{mg} \mathrm{g}^{-1}\right) \\
\mathrm{n}=11\end{array}$ \\
\hline CE278 & Certified & - & - & $0.08 \pm 0.002$ \\
& Observed & - & - & $0.10 \pm 0.001$ \\
TORT-2 & Certified & $0.11 \pm 0.01$ & $0.11 \pm 0.01$ & - \\
& Observed & $0.11 \pm 0.002$ & $0.11 \pm 0.01$ & - \\
\hline
\end{tabular}

4

5 Table 2

6 Lipids, carbohydrates and total proteins in whole soft tissues for the two groups studied. Results are presented as mean $\pm \mathrm{SD}$, in $\mathrm{mg} \mathrm{g}^{-1}$ dry weight. $\mathrm{n}$ 7 represents the number of analyzed mussels.

\begin{tabular}{ccccc}
\hline Biochemical & $\mathrm{n}$ & mussels & $\mathrm{n}$ & mussels + mats \\
\hline Lipids $^{\mathrm{a}}$ & 1 & 138.5 & 1 & 174.8 \\
Carbohydrates & 5 & $29.1 \pm 4.7$ & 5 & $36.2 \pm 9.9$ \\
Total proteins & 5 & $889.9 \pm 67.4$ & 4 & $863.3 \pm 60.9$ \\
\hline
\end{tabular}

$8 \quad{ }^{\mathrm{a}}$ pooled sample 
9 Table 3

10 In situ temperature measurements $\left({ }^{\circ} \mathrm{C}\right)$ and estimated values of $\mathrm{CH}_{4}$ and $\mathrm{H}_{2} \mathrm{~S}\left(\mu \mathrm{mol} \mathrm{l}^{-1}\right)$ obtained within the sampling sites. For temperatures measurements: $\mathrm{n}=$ 1123389 , sampling period $30 \mathrm{sec}$, results are presented as mean $\pm \mathrm{SD}$.

\begin{tabular}{|c|c|c|c|c|c|c|}
\hline & & mussels & & mussels & + mats & \\
\hline mean $\pm \mathrm{SD}$ & $\begin{array}{c}\text { Temperature } \\
\left({ }^{\circ} \mathrm{C}\right) \\
4.91 \pm 0.10\end{array}$ & $\begin{array}{l}\text { CH4 estimated } \\
(\mu \mathrm{M})\end{array}$ & $\begin{array}{c}\mathrm{H}_{2 \mathrm{~S}} \text { estimated } \\
(\mu \mathrm{M})\end{array}$ & $\begin{array}{c}\text { Temperature } \\
\left({ }^{\circ} \mathrm{C}\right) \\
5.89 \pm 0.52\end{array}$ & $\begin{array}{l}\text { CH4 estimated } \\
(\mu \mathrm{M})\end{array}$ & $\begin{array}{c}\mathrm{H} 2 \mathrm{~S}_{\mathrm{T}} \text { estimated } \\
(\mu \mathrm{M})\end{array}$ \\
\hline minimum & 4.64 & 0.06 & $<\mathrm{dl}^{*}$ & 4.76 & 0.15 & 1 \\
\hline maximum & 5.25 & 0.5 & 5 & 7.39 & 2.0 & 23 \\
\hline range & 0.61 & & & 2.63 & & \\
\hline
\end{tabular}

$* \mathrm{dl}=$ detection limit 
22 Metallothionein (MT) and metal (Cu, Fe and $\mathrm{Zn})$ levels in the tissues of the two groups studied. The "Mean per group" represents the mean levels of MT, Cu,

$23 \mathrm{Fe}$ and $\mathrm{Zn}$ for each group. Results are presented as mean $\pm \mathrm{SD}$, in $\mathrm{mg} \mathrm{g}^{-1}$ dry weight

\begin{tabular}{lcccccccc}
\hline & \multicolumn{3}{c}{ mussels } & \multicolumn{3}{c}{ mussels + mats } \\
\hline Gill & MT & $\mathrm{Cu}$ & $\mathrm{Fe}$ & $\mathrm{Zn}$ & $\mathrm{MT}$ & $\mathrm{Cu}$ & $\mathrm{Fe}$ & $\mathrm{Zn}$ \\
Mantle & $16.7 \pm 5.0$ & $0.14 \pm 0.04$ & $0.28 \pm 0.09$ & $0.23 \pm 0.06$ & $16.9 \pm 2.7$ & $0.20 \pm 0.02$ & $0.20 \pm 0.04$ & $0.21 \pm 0.04$ \\
Foot & $22.1 \pm 7.7$ & $0.08 \pm 0.04$ & $0.30 \pm 0.08$ & $0.25 \pm 0.06$ & $21.0 \pm 10.7$ & $0.07 \pm 0.02$ & $0.20 \pm 0.07$ & $0.38 \pm 0.11$ \\
Digestive gland & $20.1 \pm 29.7$ & $0.10 \pm 0.04$ & $0.28 \pm 0.05$ & $0.50 \pm 0.21$ & $21.6 \pm 9.2$ & $0.05 \pm 0.03$ & $0.20 \pm 0.09$ & $0.30 \pm 0.13$ \\
Remaining & $96.8 \pm 27.8$ & $0.18 \pm 0.05$ & $0.97 \pm 0.25$ & $0.67 \pm 0.14$ & $114.2 \pm 38.2$ & $0.20 \pm 0.09$ & $0.65 \pm 0.18$ & $0.65 \pm 0.26$ \\
Mean per group & $18.0 \pm 1.4$ & $0.07 \pm 0.01$ & $0.48 \pm 0.19$ & $0.34 \pm 0.11$ & $15.9 \pm 2.9$ & $0.07 \pm 0.04$ & $0.20 \pm 0.04$ & $0.19 \pm 0.08$ \\
& $21.5 \pm 0.2$ & $0.13 \pm 0.03$ & $0.32 \pm 0.08$ & $0.28 \pm 0.06$ & $19.1 \pm 0.2$ & $0.11 \pm 0.04$ & $0.19 \pm 0.05$ & $0.21 \pm 0.06$ \\
\hline
\end{tabular}

